\title{
Late Spring Culture of Headed Chinese Cabbage(Brassica campestris var. pekinensis)
}

\author{
Enikő LACZI*, Alexandru APAHIDEAN, Emil LUCA, Georgeta BURDUHOS \\ University of Agricultural Sciences and Veterinary Medicine Cluj-Napoca, Faculty of Horticulture, \\ Calea Mănăștur 3-5, 400372, Cluj-Napoca, Cluj, Romania \\ ${ }^{*}$ Corresponding author, e-mail: enikolaczi@yahoo.com
}

Bulletin UASVM Horticulture 72(1) / 2015

Print ISSN 1843-5254, Electronic ISSN 1843-5394

Doi:10.15835/buasvmcn-hort:10348

\begin{abstract}
The main purpose of the present research was the study of the behaviour of some headed Chinese cabbage varieties in the Transylvanian Tableland late spring specific conditions. The present research took place in the experimental field which belongs to the Vegetable Growing Department from the University of Agricultural Sciences and Veterinary Medicine Cluj-Napoca, in the spring of 2011. The results showed that Chinese cabbage can be cultivated with success in Transylvanian Tableland specific conditions even in late autumn, even if previous studies have shown that very good results can be obtained in spring and summer, but it is necessary to choose the right variety or hybrid, because of the high bolting tendency of this vegetable.
\end{abstract}

Keywords: Chinese cabbage, leafy vegetable, open field culture.

\section{INTRODUCTION}

Heading Chinese cabbage (Brassica campestris var. pekinensis) is a cold season, annual vegetable. It grows best under temperatures of $15-20^{\circ} \mathrm{C}$ degrees (Kalband Chang, 2005). This vegetable is among the fastest growing of all leafy vegetables, in favourable conditions heads being cut ten weeks after sowing (Larkcom, 2003). Earlier studies of the authors demonstrated that Chinese cabbage may be grown with success in Transylvanian Tableland, but more studies are necessary to obtain a better cultivation technology (Laczi et al., 2012; Laczi et al., 2013)

\section{AIMS AND OBJECTIVES}

The present research had as main purpose the study of the behaviour of some headed Chinese cabbage varieties in the Transylvanian Tableland late spring specific conditions. During the experiment plants growth and development was studied, while after harvest plants quality and quantity was determined.

\section{MATERIALS AND METHODS}

The present research took place in the experimental field belonging to the Vegetable Growing Department from the University of Agricultural Sciences and Veterinary Medicine Cluj-Napoca, in the spring of 2011.To achieve the objectives of this experiment a collection of 5 varieties and hybrids (Michihli, Kingdom 80, Granat (control variant), Nepa $F_{1}$, Vitimo $F_{1}$ ) was organized. Each variety and hybrid was placed into three repetitions, the size of the experimental plots being $3 \mathrm{~m}^{2}$. The seeding was made in $22^{\text {nd }}$ of March; the planting was performed in the second part of April in open field. During the vegetation period, there were not necessary any treatments or fertilizations. Harvest was realized beginning from the end of May at Granat variety, Nepa $F_{1}$, 
Tab. 1. - The parameters of Chinese cabbage growth and development ( $a$ - at planting, $b$ - one month after planting, $\mathrm{c}-$ at harvest)

\begin{tabular}{cccccccccccc}
\hline $\begin{array}{c}\text { Variaty / } \\
\text { Hybrid }\end{array}$ & \multicolumn{3}{c}{ Height $(\mathrm{cm})$} & \multicolumn{3}{c}{ Diameter (cm) } & \multicolumn{2}{c}{ Number of leaves } & $\begin{array}{c}\text { Bolting } \\
\text { ratio (\%) }\end{array}$ \\
\hline & $\mathrm{a}$ & $\mathrm{b}$ & $\mathrm{c}$ & $\mathrm{a}$ & $\mathrm{b}$ & $\mathrm{c}$ & $\mathrm{a}$ & $\mathrm{b}$ & $\mathrm{c}$ & \\
\hline Michihli & 13,67 & 34,17 & 37,83 & 19,33 & 52,50 & 57,67 & 6,00 & 17,17 & 22,33 & 25 \\
Kingdom 80 & 14,33 & 21,00 & 28,83 & 19,67 & 44,17 & 56,67 & 7,67 & 21,17 & 42,33 & 12.5 & 29.17 \\
Granat & 17,00 & 24,17 & 35,83 & 20,00 & 41,17 & 48,33 & 7,33 & 18,17 & 28,5 & 29 \\
Nepa F & 11,33 & 28,50 & 37,5 & 19,00 & 45,17 & 54,67 & 7,67 & 15,33 & 32,67 & 12.5 \\
Vitimo F & 13,67 & 18,83 & 31 & 18,33 & 42,67 & 51,17 & 7,67 & 18,67 & 49,17 & 0 \\
\hline Average & 14,00 & 25,33 & 39,83 & 19,27 & 45,13 & 37,47 & 7,27 & 18,10 & 35 & 15.83 \\
\hline
\end{tabular}

Table 2. The influence of cultivar on the yield of Chinese cabbage

\begin{tabular}{ccccc}
\hline $\begin{array}{c}\text { Variant } \\
\text { Variaty / Hybrid }\end{array}$ & $\begin{array}{c}\text { Average yield } \\
(\mathrm{t} / \mathrm{ha})\end{array}$ & $\begin{array}{c}\text { Relative yield } \\
(\%)\end{array}$ & $\begin{array}{c}\text { Difference } \\
(\mathrm{t} / \mathrm{ha})\end{array}$ & Significance \\
\hline Granat & 33.33 & 100 & 0 & $\mathrm{Ct}$. \\
Kingdom 80 & 49.87 & 149.62 & 16.54 & $* * *$ \\
Michihli & 29.87 & 89.62 & -3.46 & $* *$ \\
Nepa F1 & 46.67 & 140 & 13.34 & $* * *$ \\
Vitimo F1 & 87.47 & 262.44 & 54.14 & \\
\hline
\end{tabular}

$\overline{\mathrm{LSD}}(\mathrm{p}$ 5\%)=7.11; LSD (p 1\%)=10.35, LSD (p 0,1\%)=15.52

Michihliand Kingdom 80hybrids, to the end of June at VitimoF ${ }_{1}$ hybrid. During growing season observations were made regarding plants growth and development, while at harvest measurements were focused on production quality and quantity.

\section{RESULTS AND DISCUSSIONS}

Highest seedlings $(17 \mathrm{~cm})$, with highest diameter $(20 \mathrm{~cm})$, were those which belonged to Granat variety, while the highest plant weight was registered at Nepa $\mathrm{F}_{1}$ hybrid $(11.50 \mathrm{~cm})$. One month after plantingand at harvest Michihli hybrid registered higher values from plants height (34.17 $\mathrm{cm} ; 37.83 \mathrm{~cm})$ and diameter $(52.50 \mathrm{~cm} ; 57.67$ $\mathrm{cm})$ point of view, while Kingdom 80 hybrid had the most leaves one month after planting (18.67) and VitimoF $F_{1}$ hybridat harvest (49.17) (tab. 1). Regarding the bolting ratio it was observed that only at VitimoF ${ }_{1}$ hybrid there were not bolted plants at harvest, the average bolting ratio having a value of $15.83 \%$. The lowest yield (29.87 t/ ha) was registered at Michihli hybrid, while the highest one (87.47 t/ha) at VitimoF ${ }_{1}$ hybrid (tab. $1)$. Very significant positive differences were registered at Kingdom 80 and Vitimo F1 hybrids and a different significant positive one at Nepa F1 hybrid compared to Granat, the control variety. No statistically assured difference was between control variant and Michihli hybrid (tab. 2).

\section{CONCLUSIONS}

To grow Chinese cabbage in late spring in Transylvanian Tableland conditions is necessary to choose the right variety or hybrid, because of the high bolting tendency. Taking into consideration the results of this study, VitimoF Fybrid is $_{1}$ recommended for cultivation in this area, so that a high yield of good quality could be obtain.

Acknowledgments. This paper was published under the frame of European Social Fund, HumanResources Development Operational Programme 2007-2013, project no. POSDRU/159/ 1.5/S/132765.

\section{REFERENCES}

1. Kalb T, Chang LC (2005). Suggested cultural practices for heading Chinese cabbage. AVR DG pub.: 5-642.

2. Laczi E, Apahidean AS (2012). Protected culture study of Chinese cabbage (Brassica campestris var. pekinensis) varieties and hybrids collection grown in the Transylvanian Tableland specific conditions. Brukenthal. Acta Musei VII. 3:579-588.

3. Laczi E, Apahidean AS, Dumitraș A, Boancă P, Apahidean AI, Tomoş C (2013). Growing Chinese Cabbage: Indoor or Outdoor?. Bulletin UASVM Horticulture 70(1): 251-252.

4. Larkcom J (2003). The organic salad garden.Frances Lincoln Limited. London: 31-33. 